Muh. Hatta : Pertumbuhan dan Produksi beberapa Varietas Tanaman Jagung (Zea mays L. dengan Pemberian berbagai Dosis Pupuk Organik Cair dan Pupuk Kandang

\title{
PERTUMBUHAN DAN PRODUKSI BEBERAPA VARIETAS TANAMAN JAGUNG (Zea mays $l$.) DENGAN PEMBERIAN BERBAGAI DOSIS PUPUK ORGANIK CAIR DAN PUPUK KANDANG
}

\author{
Growth and Production of Several Corn (Zea mays l.) Varieties Given Various Doses of \\ Liquid Organic Fertilizer and Manure \\ Hatta. M*1, Saida*2 ${ }^{2}$ A. Haris $*^{2}$ \\ ${ }^{1}$ Mahasiswa Program Studi Magister Agroteknologi, Program Pascasarjana UMI, Makassar \\ ${ }^{2}$ Dosen Prodi Agroteknologi Fak. Pertanian UMI, Makassar \\ Email : ${ }^{1}$ muhatta456@gamail.com, ${ }^{2}$ saida.saida@umi.ac.id
}

\begin{abstract}
This research aims to determine the effect of varieties and fertilization combinations between liquid organic fertilizer and manure and the interaction of both that provide the best growth and production. This research was carried out in the Religion Agro Tourism garden in Padanglampe Village, Ma'rang District, Pangkajene Regency and the Islands of South Sulawesi Province, from January to May 2020. The experimental design used was a split plot design with two factors, namely variety and a combination of liquid organic fertilizer with manure, variety as the main factor consisted of three levels, namely BISI-18 variety, NASA29 variety and Pertiwi-5 variety. The combination of liquid organic fertilizer with manure as a plot consists of four levels, namely Control, a combination of liquid organic fertilizer with chicken manure, a combination of liquid organic fertilizer with cow manure, a combination of liquid organic fertilizer with manure and cow manure. Data were analyzed by variance using the F Test. The difference in the mean value of the treatment would be tested with Tukey's HSD (honestly significant difference) test at the $0.05 \%$ level.

The results showed that (1) The treatment of three varieties did not significantly affect all observed parameters. But the Pertiwi-5 variety tends to be the best compared to other varieties. (2) The treatment of fertilizer combination between liquid organic fertilizer and manure significantly influences all of the monitoring parameters. The combination of liquid organic fertilizer $5 \mathrm{cc} / l$. Water with Chicken manure 15 tons / ha and Cow manure 15 tons / ha tend to have a pretty good effect, by showing the dry shell weight per hectare of 8.75 tons / ha. (3) The interaction between varieties with a combination of liquid organic fertilizer and manure does not significantly affect all observation parameters. But the interaction between Pertiwi-5 varieties with a combination of liquid organic fertilizer $5 \mathrm{cc} / \mathrm{l}$. Water with Chicken manure 15 tons / ha and Cow manure 15 tons / ha tend to be the best compared to other interactions
\end{abstract}

Keywords: growth, varieties, corn, liquid organic fertilizer

\section{PENDAHULUAN}

Jagung (Zea mays l.) merupakan bagian dari sub sektor tanaman pangan yang memberikan andil bagi pertumbuhan industri hulu dan pendorong industri hilir yang kontribusinya pada pertumbuhan ekonomi nasional cukup besar. Tanaman jagung juga merupakan salah satu komoditi strategis dan bernilai ekonomis serta mempunyai peluang untuk dikembangkan karena kedudukannya sebagai sumber utama karbohidrat dan protein setelah beras (Anonim, 2003).

Upaya untuk memenuhi permintaan jagung dibutuhkan teknologi yang dapat meningkatkan produktivitas dan produksi. 
Hal yang dapat dilakukan antara lain dengan perbaikan teknik budidaya, yaitu penggunaan varietas unggul dan penggunaan pupuk yang berimbang serta penggunan pupuk organik yang optimal.

Salah satu upaya untuk meningkatkan produktivitas jagung adalah menggunakan varietas unggul yang berdaya hasil tinggi dan adaptif dengan lingkungan setempat. Pengembangan varietas unggul baik dari jenis hibrida maupun bersari bebas, telah berkontribusi nyata terhadap peningkatan produktivitas. Peran varietas unggul sangat strategis karena terkait dengan beberapa hal yakni: (a) dapat meningkatkan hasil per satuan luas tanam, (b) ketahanan terhadap hama dan penyakit tertentu, (c) daya adaptasi atau kesesuaian pada wilayah atau ekosistem spesifik, dan (d) merupakan komponen teknologi yang relatif mudah/cepat diadopsi petani (Subandi 2003). Namun distribusi varietas unggul tersebut berjalan lambat. Nugraha dan Subandi (2002) melaporkan bahwa dari 19 propinsi yang disurvei, jumlah penggunaan varietas unggul baru mencapai $75 \%$ yang terdiri atas $48 \%$ bersari bebas dan $27 \%$ hibrida. Dari $27 \%$ penggunaan hibrida, sebagian menggunakan benih regenerasi. Beberapa varietas hibrida sudah banyak beredar di masyarakat antara lain varietas Bisi, NASA29, dan Pertiwi. Masing-masing varietas hibrida tersebut mempunyai potensi dan rata-rata hasil yang tinggi.

Varietas merupakan salah satu di antara banyak faktor yang menentukan dalam pertumbuhan dan hasil tanaman. Selain faktor lingkungan, penggunaan varietas unggul merupakan salah satu komponen teknologi yang sangat penting untuk mencapai produksi yang tinggi. Penggunaan varietas unggul mempunyai kelebihan dibandingkan dengan varietas lokal dalam hal produksi dan ketahanan terhadap hama dan penyakit, respons pemupukan sehingga produksi yang di peroleh baik kuantitas maupun kualitas dapat meningkat (Soegito dan Adie, 1993).

Selain varietas, penggunaan pupuk berimbang serta penggunaan pupuk organik optimal dan tepat akan meningkatkan produksi jagung. Tanaman jagung sangat respons terhadap tanah dengan kesuburan tinggi. Selaras dengan pernyataan di atas dalam hal pengolahan tanah harus diperhatikan aspek pemupukan. Dalam pemupukan ketepatan dosis, cara dan waktu pemupukan yang tepat sangat penting agar produksi optimum. Pupuk yang biasa diberikan dalam budidaya jagung manis adalah pupuk arganik (alami) dan pupuk buatan (kimia). Pupuk organik yang umum diberikan yaitu pupuk kandang dan pupuk hijau, sedangkan pupuk buatan yang umum diberikan adalah urea, $\mathrm{KCl}$, NPK dan SP 36 yang diberikan pada saat penanaman (Hardjodinomo, 1970; Sahoo and Mahapatra, 2007 ).

Pupuk kandang merupakan salah satu pupuk organik yang mengandung hara makro dan hara mikro, yang dapat memperbaiki sifat- sifat fisik, kimia dan biologi tanah (Marsono, 2001). Pupuk kandang dapat berasal dari kotoran sapi, 
ayam atau bebek yang benar-benar telah matang yang dapat digunakan sebagai pupuk dasar atau pupuk susulan. Selain itu pupuk kandang dapat menghasilkan hormon sitokinin dan giberelin yang dapat merangsang pertumbuhan tanaman. Jumlah pupuk kandang yang diberikan ke dalam tanah berkisar antara 20-30 ton/ha. Cara pemberiannya tergantung pada jenis tanaman yaitu dapat dengan cara disebar merata di atas permukaan tanah (Cahyono, 1998).

Pupuk organik cair kebanyakan diaplikasikan melalui daun atau disebut sebagai pupuk cair foliar yang mengandung hara makro dan mikro esensial $(\mathrm{N}, \mathrm{P}, \mathrm{K}, \mathrm{S}$, $\mathrm{Ca}, \mathrm{Mg}, \mathrm{B}, \mathrm{Mo}, \mathrm{Cu}, \mathrm{Fe}, \mathrm{Mn}$, dan bahan organik). Pupuk organik cair selain dapat memperbaiki sifat fisik, kimia, dan biologi tanah, juga membantu meningkatkan produksi tanaman, meningkatkan kualitas hasil tanaman, mengurangi penggunaan pupuk anorganik dan sebagai alternatif pengganti pupuk kandang.

Pemberian pupuk organik cair harus memperhatikan konsentrasi atau dosis yang diaplikasikan terhadap tanaman. Beberapa hasil penelitian menunjukkan bahwa pemberian pupuk organik cair melalui daun memberikan pertumbuhan dan hasil tanaman yang lebih baik daripada pemberian melalui tanah. Semakin tinggi dosis pupuk yang diberikan maka kandungan unsur hara yang diterima oleh tanaman akan semakin tinggi, begitu pula dengan semakin seringnya frekuensi aplikasi pupuk daun yang dilakukan pada tanaman, maka kandungan unsur hara juga semakin tinggi. Namun, pemberian dengan dosis yang berlebihan justru akan mengakibatkan timbulnya gejala kelayuan pada tanaman.

Penelitian ini bertujuan untuk mengetahui jenis varietas yang memberikan pertumbuhan dan produksi terbaik. (2) mengetahui pengaruh kombinasi pupuk organik cair dan pupuk kandang terhadap pertumbuhan dan produksi tanaman jagung. (3) Untuk mengetahui interaksi antara varietas dengan pupuk organik cair yang di kombinasikan dengan pupuk kandang terhadap pertumbuhan dan produksi tanaman jagung.

\section{BAHAN DAN METODE}

Penelitian dilaksanakan pada bulan Januari-Mei 2020, bertempat di Kebun Agro Wisata Relegius Desa Padanglampe Kecamatan Sigeri Kabupaten Pangkajene dan Kepulauan Provinsi Sulawesi Selatan. Bahan yang digunakan dalam penelitian yaitu benih jagung varietas BISI-18, Pertiwi-5, NASA 29, Pupuk Organik Cair, Pupuk Kandang Sapi dan Ayam. Alat yang digunakan adalah Hand Traktor, cangkul, tugal, tali rapia, ajir, meteran dan timbangan.

Penelitian ini disusun berdasarkan rancangan petak terbagi (RPT) dengan 12 kombinasi perlakuan yang diulang sebanyak 3 kali. Varietas diletakkan sebagai petak utama dan kombinasi POC dengan pupuk kandang sebagai anak petak.
1. Petak Utama adalah Varietas (V) terdiri dari 
Muh. Hatta : Pertumbuhan dan Produksi beberapa Varietas Tanaman Jagung (Zea mays L. dengan Pemberian berbagai Dosis Pupuk Organik Cair dan Pupuk Kandang

VI : Varietas BISI-18

V2: Varietas Pertiw-5

V3 : Varietas NASA-29

2. Anak Petak adalah Kombinasi Pupuk Organik Cair dengan Pupuk Kadang terdiri dari :

P0 : Tanpa Perlakuan (Kontrol)

P1 : $5 \mathrm{cc} / \mathrm{l}$ air dan 20 ton/ha Pupuk

Kandang Ayam

P2 : $5 \mathrm{cc} / \mathrm{l}$ air dan 20 ton/ha Pupuk

Kandang Sapi

P3 : 5 cc/l air dan 15 ton/ha Pupuk

Kandang Ayam Serta 15 ton/ha Pupuk

Kandang Sapi

Adapun variable pengamatan yaitu : 1) Tinggi Tanaman. 2) Jumlah daun. 3) Panjang Daun. 4) Diameter Batang. 5) Panjang Tongkol. 6) Diameter Tongkol. 7) Bobot Pipilan Kering Per Tongkol. 8) Bobot Tongkol Per Petak. 9) Bobot Pipilan 100 Biji. 10) Bobot Tongkol Per Hektar. 11) Bobot pipilan kering per hektar.

Data yang diperoleh di analisis ragam taraf signifikan 5\%. Bila terdapat pengaruh yang signifikan dilakukan uji lanjut dengan mengunakan uji BNJ (Beda Nyata Jujur) pada taraf signifikasi 5\%.

\section{HASIL DAN PEMBAHASAN \\ Tinggi Tanaman}

Berdasarkan hasil uji lanjutan BNJ $\alpha$ 0.05 (Tabel 1) menunjukan bahwa varietas
Pertiwi-5 (V3) berbeda nyata dengan varietas BISI-18 (V1) dan varietas NASA29 (V2). Hal ini dapat dilihat bahwa varietas Pertiwi-5 (V3). menunjukan rata-rata tinggi tanaman tertinggi yaitu $25,92 \mathrm{~cm}$.

Selanjutnya pada perlakuan kombinasi pemupukan, berdasarkan hasil uji lanjutan BNJ $\alpha 0.05$ (Tabel 1) menunjukan bahwa perlakuan P3 berbeda nyata dengan perlakuan P0 dan P2, namun antara P3 dan P1 tidak berbeda nyata, demikian pula antara perlakuan $\mathrm{P} 0, \mathrm{P} 1$ dan $\mathrm{P} 2$ juga tidak berbeda nyata terhadap pengamatan tinggi tanaman pada umur 15 HST. Selanjutnya pada umur 30 dan 45 HST menunjukan bahwa antara perlakuan P3 dan P1 tidak memperlihatkan berbeda nyata, demikian pula dengan perlakuan P0 dan P2 juga tidak berbeda nyata, namun antara perlakuan $\mathrm{P} 3$ dan P1 memberikan respon yang berbeda nyata dibandingkan dengan perlakuan $\mathrm{P} 0$ dan P2. Sedangkan pada umur 60 HST menunjukan bahwa perlakuan P3 berbeda nyata dengan perlakuan P0 dan P2, demikian juga dengan perlakuan P1 berbeda nyata dengan perlakuan $\mathrm{P} 0$. Namun antara perlakuan P3 dengan perlakuan P1 tidak menunjukan berbeda nyata, demikian pula antara perlakuan P1 dan P2 juga tiddak berbeda nyata, begitupun dengan perlakuan P2 dan P0 juga tidak berbeda nyata. 
Muh. Hatta : Pertumbuhan dan Produksi beberapa Varietas Tanaman Jagung (Zea mays L. dengan Pemberian berbagai Dosis Pupuk Organik Cair dan Pupuk Kandang

Tabel 1. Rataan Tinggi Tanaman Pada Umur 15-60 HST Pada Pemberian Berbagai Dosis Pupuk Organik Cair Serta Pupuk Kandang

\begin{tabular}{ccccc}
\hline \multirow{2}{*}{ Perlakuan } & \multicolumn{4}{c}{ Tinggi Tanaman $(\mathrm{cm})$} \\
\cline { 2 - 5 } Varietas (V) & 15 HST & 30 HST & 45 HST & 60 HST \\
\hline V1 & $20.12^{\mathrm{a}}$ & tn & tn & tn \\
\hline V2 & $22.22^{\mathrm{a}}$ & 76.03 & 153.85 & 181.99 \\
V3 & $25.92^{\mathrm{b}}$ & 79.44 & 145.71 & 174.65 \\
\hline NP BNJ 0.05 & 4.82 & 8.85 & 28.16 & 28.14 \\
\hline Pemupukan (P) & $*$ & $*$ & $*$ & $*$ \\
\hline P0 & $19.24^{\mathrm{a}}$ & $65.37^{\mathrm{a}}$ & $118.39^{\mathrm{a}}$ & $148.02^{\mathrm{a}}$ \\
P1 & $22.93^{\mathrm{ab}}$ & $84.96^{\mathrm{b}}$ & $174.35^{\mathrm{b}}$ & $194.72^{\mathrm{bc}}$ \\
P2 & $21.36^{\mathrm{a}}$ & $67.54^{\mathrm{a}}$ & $138.28^{\mathrm{a}}$ & $171.50^{\mathrm{ab}}$ \\
P3 & $27.46^{\mathrm{b}}$ & $91.57^{\mathrm{b}}$ & $178.78^{\mathrm{b}}$ & $206.80^{\mathrm{c}}$ \\
\hline NP BNJ 0.05 & 5.27 & 12.41 & 30.12 & 31.01 \\
\hline Interaksi (V / P) & tn & tn & tn & tn \\
\hline V1P0 & 18.47 & 64.84 & 117.72 & 148.06 \\
V1P1 & 18.63 & 82.89 & 184.94 & 202.44 \\
V1P2 & 20.08 & 67.72 & 138.06 & 169.56 \\
V1P3 & 23.28 & 91.06 & 174.67 & 207.89 \\
V2P0 & 18.48 & 66.11 & 122.72 & 151.28 \\
V2P1 & 21.33 & 81.56 & 155.61 & 185.94 \\
V2P2 & 21.11 & 63.56 & 130.17 & 166.22 \\
V2P3 & 27.94 & 92.83 & 174.33 & 195.17 \\
V3P0 & 20.78 & 65.17 & 114.72 & 144.72 \\
V3P1 & 28.83 & 90.44 & 182.5 & 195.78 \\
V3P2 & 22.89 & 71.33 & 146.61 & 178.72 \\
V3P3 & 31.17 & 90.83 & 187.33 & 217.33 \\
\hline V2 & &
\end{tabular}

Keterangan : Angka yang diikuti oleh huruf yang sama pada kolom (a,b,c) berarti perlakuan berpengaruh tidak nyata pada taraf uji $\mathrm{BNJ} \alpha 0.05{ }^{*}=$ berpengaruh nyata, tn = berpengaruh tidak nyata

\section{Jumlah Daun}

Hasil uji BNJ a 0.05 (Tabel 2) jumlah daun pada umur 15 HST menunjukan bahwa perlakuan $\mathrm{P}_{3}$ berbeda nyata dengan perlakuan $\mathrm{P}_{0}, \mathrm{P}_{1}$ dan $\mathrm{P}_{2}$ demikian pula perlakuan $\mathrm{P}_{1}$ berbeda nyata dengan perlakuan P0. Namun antara perlakuan $\mathrm{P}_{1}$ dengan $\mathrm{P}_{2}$ tidak berbeda nyata, demikan pula antara perlakuan $\mathrm{P}_{0}$ dan $\mathrm{P}_{2}$ tidak berbeda nyata. Sedangkan pada umur 30 , 45 dan 60 HST menunjukan bahwa perlakuan $\mathrm{P}_{3}$ berbeda nyata dengan perlakuan $\mathrm{P}_{0}, \mathrm{P}_{1}$ dan $\mathrm{P}_{2}$. Hal ini dapat dilihat bahwa perlakuan $\mathrm{P}_{3}$ memberikan pengaruh yang cukup baik dengan rata-rata jumlah daun terbanyak terdapat pada $\mathrm{P}_{3}$ yaitu 12.48 helai pada umur 60 HST. 
Muh. Hatta : Pertumbuhan dan Produksi beberapa Varietas Tanaman Jagung (Zea mays L. dengan Pemberian berbagai Dosis Pupuk Organik Cair dan Pupuk Kandang

Tabel 2. Rataan Jumlah Daun Pada Umur 15-60 HST Pada Pemberian Berbagai Dosis Pupuk Organik Cair Serta Pupuk Kandang

\begin{tabular}{ccccc}
\hline \multirow{2}{*}{ Perlakuan } & \multicolumn{5}{c}{ Jumlah Daun (helai) } \\
\cline { 2 - 5 } & 15 HST & 30 HST & 45 HST & 60 HST \\
\hline Varietas (V) & tn & tn & tn & tn \\
\hline V1 & 2.82 & 7.03 & 10.13 & 11.90 \\
V2 & 3.63 & 6.67 & 9.14 & 11.46 \\
V3 & 3.84 & 6.53 & 10.10 & 11.93 \\
\hline NP BNJ 0.05 & 0.53 & 0.93 & 1.07 & 0.70 \\
\hline Pemupukan & tn & $*$ & $*$ & $*$ \\
\hline P0 & 3.21 & $5.61^{\mathrm{a}}$ & $8.39^{\mathrm{a}}$ & $10.54^{\mathrm{a}}$ \\
P1 & 3.41 & $7.28^{\mathrm{b}}$ & $10.31^{\mathrm{b}}$ & $12.1 \mathrm{~b}$ \\
P2 & 3.13 & $6.33^{\mathrm{ab}}$ & $9.74^{\mathrm{b}}$ & $11.89^{\mathrm{b}}$ \\
P3 & 3.97 & $7.74^{\mathrm{c}}$ & $10.70^{\mathrm{b}}$ & $12.48^{\mathrm{b}}$ \\
\hline NP BNJ 0.05 & 0.65 & 1.05 & 1.21 & 0.78 \\
\hline Interaksi (V/P) & tn & tn & tn & tn \\
\hline V1P0 & 2.89 & 6.11 & 9.00 & 10.5 \\
V1P1 & 2.50 & 7.44 & 10.5 & 12.39 \\
V1P2 & 2.75 & 6.78 & 10.11 & 12.11 \\
V1P3 & 3.14 & 7.78 & 10.89 & 12.61 \\
V2P0 & 3.42 & 5.83 & 7.89 & 10.06 \\
V2P1 & 3.53 & 6.94 & 9.39 & 11.83 \\
V2P2 & 3.25 & 6.11 & 8.83 & 11.56 \\
V2P3 & 4.33 & 7.78 & 10.44 & 12.39 \\
V3P0 & 3.33 & 4.89 & 8.28 & 11.06 \\
V3P1 & 4.19 & 7.44 & 11.06 & 12.22 \\
V3P2 & 3.39 & 6.11 & 10.28 & 12.00 \\
V3P3 & 4.44 & 7.67 & 10.78 & 12.44 \\
\hline V19 & & &
\end{tabular}

Keterangan : Angka yang diikuti oleh huruf yang sama pada kolom $(a, b, c)$ berarti perlakuan tidak berpengaruh nyata pada taraf uji BNJ $\alpha 0.05$.

\section{Panjang Daun}

* = berpengaruh nyata, $\mathrm{tn}=$ berpengaruh tidak nyata

Hasil analisis ragam panjang daun perlakuan $\mathrm{P}_{3}$ dan $\mathrm{P}_{1}$ tidak berbeda nyata, pada umur 15, 30, 45 dan 60 HST, demikian pula antara $P_{1}$ dan $P_{2}$ juga tidak menunjukan bahwa taraf pemupukkan berbeda nyata, begitu pula dengan kombinasi antara pupuk organik cair perlakuan P2 dan P0 juga tidak berbeda dengan pupuk kandang berpengaruh nyata, tetapi varietas dan interaksi keduanya berpengaruh tidak nyata.

Berdasarkan hasil uji BNJ $\alpha 0.05$ (Tabel 3) pada umur 15 dan 30 HST menunjukan bahwa perlakuan $\mathrm{P}_{3}$ berbeda nyata dengan perlakuuan $\mathrm{P}_{2}$ dan $\mathrm{P}_{0}$, demikian pula dengan $\mathrm{P}_{1}$ berbeda nyata dengan perlakuan $\mathrm{P}_{0}$. Namun antara nyata terhadap panjang daun pada umur 15 dan 30 HST. Selanjut pada umur 45 HST menunjukan bahwa perlakuan $\mathrm{P}_{3}$ berbeda nyata dengan perlakuan $\mathrm{P}_{2}$ dan $\mathrm{P}_{0}$, demikian pula antara perlakuan $\mathrm{P}_{1}$ dan $\mathrm{P}_{2}$ berbeda nyata dengan perlakuan $P_{0}$. Namun antara perlakuan $\mathrm{P}_{3}$ dengan $\mathrm{P}_{1}$ tidak berbeda nyata, demikian pula antara perlakuan P1 dan P2 juga tidak berbeda 
Muh. Hatta : Pertumbuhan dan Produksi beberapa Varietas Tanaman Jagung (Zea mays L. dengan Pemberian berbagai Dosis Pupuk Organik Cair dan Pupuk Kandang

nyata. Sedangkan pada umur 60 HST antara perlakuan $\mathrm{P}_{3}, \mathrm{P}_{2}$ dan $\mathrm{P}_{1}$ tidak berbeda menunjukan bahwa perlakuan $\mathrm{P}_{3}, \mathrm{P}_{2}$ dan $\mathrm{P}_{1}$ nyata.

berbeda nyata dengan perlakuan $\mathrm{P}_{0}$, namun

Tabel 3. Rataan Panjang Daun Pada Umur 15-60 HST Pada Pemberian Berbagai Dosis Pupuk Organik Cair Serta Pupuk Kandang

\begin{tabular}{ccccc}
\hline \multirow{2}{*}{ Perlakuan } & \multicolumn{4}{c}{ Panjang Daun $(\mathrm{cm})$} \\
\cline { 2 - 5 } & 15 HST & 30 HST & 45 HST & 60 HST \\
\hline Varietas (V) & tn & tn & tn & tn \\
\hline V1 & 13.04 & 57.9 & 90.27 & 101.01 \\
V2 & 15.35 & 59.71 & 91.74 & 114.17 \\
V3 & 13.87 & 64.58 & 90.82 & 101.21 \\
\hline NP BNJ 0.05 & 3.81 & 8.88 & 6.20 & 7.03 \\
\hline Pemupukan & $*$ & $*$ & $*$ & $*$ \\
\hline P0 & $10.59^{\mathrm{a}}$ & $50.20^{\mathrm{a}}$ & $81.74^{\mathrm{a}}$ & $92.13^{\mathrm{a}}$ \\
P1 & $14.93^{\mathrm{bc}}$ & $65.44^{\mathrm{bc}}$ & $94.67^{\mathrm{bc}}$ & $104.30^{\mathrm{b}}$ \\
P2 & $13.05^{\mathrm{ab}}$ & $57.51^{\mathrm{ab}}$ & $89.17^{\mathrm{b}}$ & $100.57^{\mathrm{b}}$ \\
P3 & $17.77^{\mathrm{c}}$ & $69.77^{\mathrm{c}}$ & $98.19^{\mathrm{c}}$ & $108.19^{\mathrm{b}}$ \\
\hline NP BNJ 0.05 & 4.28 & 9.75 & 6.99 & 7.90 \\
\hline Interaksi (V/P) & tn & tn & tn & tn \\
\hline V1P0 & 10.47 & 46.66 & 81.01 & 81.01 \\
V1P1 & 14.76 & 64.48 & 94.39 & 94.39 \\
V1P3 & 12.79 & 50.03 & 87.83 & 87.83 \\
V2P0 & 14.12 & 70.43 & 97.83 & 97.83 \\
V2P1 & 11.04 & 51.76 & 83.83 & 83.83 \\
V2P2 & 14.93 & 61.29 & 96.11 & 96.11 \\
V2P3 & 13.92 & 57.36 & 87.11 & 87.11 \\
V3P0 & 21.49 & 68.45 & 99.89 & 99.89 \\
V3P1 & 10.24 & 52.18 & 80.39 & 80.39 \\
V3P2 & 15.09 & 70.56 & 93.5 & 93.5 \\
V3P3 & 12.43 & 65.13 & 92.56 & 92.56 \\
\hline Kete & 70.43 & 96.83 & 96.83 \\
\hline
\end{tabular}

Keterangan : Angka yang diikuti oleh huruf yang sama pada kolom (a,b,c) berarti perlakuan tidak berpengaruh nyata pada taraf uji BNJ $\alpha 0.05$.

* = berpengaruh nyata, $\mathrm{tn}=$ berpengaruh tidak nyata.

\section{Diameter Batang}

Hasil analisis ragam diameter batang pada umur 15, 30, 45 dan 60 HST, menunjukan bahwa perlakuan kombinasi antara pupuk organik cair dengan pupuk kandang berpengaruh nyata, tetapi perlakuan varietas dan interaksi keduanya tidak berpengaruh nyata.

Berdasarkan hasil uji BNJ $\alpha \quad 0.05$ (Tabel 4) menunjukan bahwa perlakuan $\mathrm{P}_{3}$ berbeda nyata dengan perlakuan $\mathrm{P}_{0}, \mathrm{P}_{1}$ dan $\mathrm{P}_{2}$, demikian pula dengan perlakuan $\mathrm{P}_{1}$ dan $P_{2}$ juga berbeda nyata dengan perlakuan $P_{0}$, namun antara perlakuan $\mathrm{P}_{1}$ dan $\mathrm{P}_{2}$ tidak berbeda nyata terhadap diameter batang pada umur 15 HST. Selanjutnya pada umur 30 HST menunjukan bahwa perlakuan $\mathrm{P}_{3}$ berbeda nyata dengan perlakuan $\mathrm{P}_{2}$ dan $\mathrm{P}_{0}$, namun antara perlakuan $\mathrm{P}_{3}$ dan $\mathrm{P}_{1}$ tidak berbeda nyata, demikian pula dengan 
perlakuan $\mathrm{P}_{2}$ dan $\mathrm{P}_{0}$ juga tidak berbeda nyata, Sedangkan pada umur 45 dan 60 HST taraf pemupukan $\mathrm{P}_{3}$ berbeda nyata dengan perlakuan $\mathrm{P}_{0}$, namun antara perlakuan $\mathrm{P}_{3}, \mathrm{P}_{1}$ dan $\mathrm{P}_{2}$ tidak berbeda nyata.

Tabel 4. Rataan Diameter Batang (cm) Pada Umur 15-60 HST Pada Pemberian Berbagai Dosis Pupuk Organik Cair Serta Pupuk Kandang

\begin{tabular}{ccccc}
\hline \multirow{2}{*}{ Perlakuan } & \multicolumn{4}{c}{ Diameter Batang (cm) } \\
\cline { 2 - 5 } & 15 HST & 30 HST & 45 HST & 60 HST \\
\hline Varietas (V) & tn & tn & tn & tn \\
\hline V1 & 0.40 & 0.90 & 1.75 & 2.08 \\
V2 & 0.38 & 0.88 & 1.87 & 2.17 \\
V3 & 0.48 & 1.01 & 1.96 & 2.29 \\
\hline NP BNJ 0.05 & 0.11 & 0.22 & 0.29 & 0.31 \\
\hline Pemupukan & $*$ & $*$ & $*$ & $*$ \\
\hline P0 & $0.26^{\mathrm{a}}$ & $0.68^{\mathrm{a}}$ & $1.46^{\mathrm{a}}$ & $1.78^{\mathrm{a}}$ \\
P1 & $0.44^{\mathrm{b}}$ & $1.05^{\mathrm{b}}$ & $2.07^{\mathrm{b}}$ & $2.39^{\mathrm{b}}$ \\
P2 & $0.40^{\mathrm{b}}$ & $0.80^{\mathrm{a}}$ & $1.84^{\mathrm{b}}$ & $2.16^{\mathrm{b}}$ \\
P3 & $0.57^{\mathrm{c}}$ & $1.19^{\mathrm{b}}$ & $2.07^{\mathrm{b}}$ & $2.39^{\mathrm{b}}$ \\
\hline NP BNJ 0.05 & 0.12 & 0.24 & 0.33 & 0.35 \\
\hline Interaksi (V/P) & tn & tn & tn & tn \\
\hline V1P0 & 0.27 & 0.66 & 1.41 & 1.74 \\
V1P1 & 0.42 & 0.98 & 1.92 & 2.25 \\
V1P2 & 0.33 & 0.74 & 1.73 & 2.04 \\
V1P3 & 0.58 & 1.22 & 1.94 & 2.27 \\
V2P0 & 0.24 & 0.65 & 1.59 & 1.88 \\
V2P1 & 0.36 & 0.99 & 2.05 & 2.34 \\
V2P3 & 0.38 & 0.69 & 1.76 & 2.05 \\
V3P0 & 0.51 & 1.18 & 2.08 & 2.39 \\
V3P1 & 0.28 & 0.73 & 1.39 & 1.71 \\
V3P2 & 0.53 & 1.18 & 2.24 & 2.57 \\
V3P3 & 0.48 & 0.96 & 2.02 & 2.37 \\
\hline Keterangan & 0.62 & 1.17 & 2.18 & 2.51 \\
\hline Ana yan & 0.39 & \\
\hline
\end{tabular}

Keterangan: Angka yang diikuti oleh huruf yang sama pada kolom (a,b,c) berarti perlakuan tidak berpengaruh nyata pada taraf uji BNJ $\alpha 0.05$.

$*$ = berpengaruh nyata, $\mathrm{tn}=$ berpengaruh tidak nyata

\section{Panjang Tongkol}

Hasil analisis ragam diameter panjang tongkol, menunjukan bahwa perlakuan varietas dan kombinasi antara pupuk organik cair dengan pupuk kandang berpengaruh nyata, tetapi interaksi keduanya berpengaruh tidak nyata. 
Muh. Hatta : Pertumbuhan dan Produksi beberapa Varietas Tanaman Jagung (Zea mays L. dengan Pemberian berbagai Dosis Pupuk Organik Cair dan Pupuk Kandang

Tabel 5. Rataan Panjang Tongkol $(\mathrm{cm})$ pada Pemberian Berbagai Dosis Pupuk Organik Cair Serta Pupuk Kandang

\begin{tabular}{|c|c|c|c|c|c|c|}
\hline \multirow{2}{*}{ Varietas } & \multicolumn{4}{|c|}{ Pemupukan } & \multirow{2}{*}{ Rata-rata } & \multirow{2}{*}{ NP BNJ 0,05 } \\
\hline & P0 & P1 & P2 & P3 & & \\
\hline V1 & 17.72 & 19.06 & 18.44 & 18.89 & $18.53^{\mathrm{a}}$ & \multirow{3}{*}{0.58} \\
\hline $\mathrm{V} 2$ & 18.22 & 19.39 & 18.61 & 19.44 & $18.92^{\mathrm{a}}$ & \\
\hline V3 & 18.89 & 19.61 & 19.28 & 19.83 & $19.40^{\mathrm{b}}$ & \\
\hline Rata-rata & $18.28^{\mathrm{a}}$ & $19.35^{\mathrm{b}}$ & $18.78^{\mathrm{ab}}$ & $19.39^{\mathrm{b}}$ & & \\
\hline NP BNJ 0.05 & \multicolumn{5}{|c|}{0.61} & \\
\hline
\end{tabular}

Keterangan: Angka yang diikuti oleh huruf yang sama pada kolom $(a, b, c)$ dan baris $(a, b, c)$, berarti perlakuan berpengaruh tidak nyata pada taraf uji BNJ $\alpha 0.05$.

Berdasarkan hasil uji BNJ $\alpha 0.05$ (Tabel 5) menunjukan bahwa perlakuan varietas V3 berbeda nyata dengan varietas V1 dan V2, namun antara varietas V1 dan V2 tidak berbeda nyata. Hal ini dapat dilihat bahwa varietas V3 memberikan respon yang cukup baik dengan rata-rata panjang tongkol terpanjang yaitu $19.40 \mathrm{~cm}$.

Selanjutnya pada perlakuan pemupukan berdasarkan hasil uji BNJ $\alpha$ 0.05 (Tabel 5) menunjukan antara taraf pemupukan P3 berbeda nyata dengan perlakuan $\mathrm{P} 0$, begitu juga dengan perlakuan P1 berbeda nyata dengan perlakuan $\mathrm{P} 0$, namun antara perlakuan P3, P1 dan P2 tidak berbeda nyata, demikian pula dengan perlakuan P2 dan P0 juga tidak berbeda nyata.

\section{Diameter Tongkol}

Hasil analisis ragam diameter tongkol, menunjukan bahwa perlakuan kombinasi antara pupuk organik cair dengan pupuk kandang menunjukkan berpengaruh nyata, tetapi perlakuan varietas serta interaksi keduanya berpengaruh tidak nyata.

Berdasarkan hasil uji BNJ $\alpha 0.05$ (Tabel 6) menunjukan bahwa perlakuan P3 berbeda nyata dengan perlakuan $\mathrm{P} 0$, namun antara perlakuan P3, P2 dan P1 tidak berbeda nyata, demikian pula dengan perlakuan P2 dan P0 tidak berbeda nyata.

Tabel 6. Rataan Diameter Tongkol (cm) Pada Pemberian Berbagai Dosis Pupuk Organik Cair Serta Pupuk Kandang

\begin{tabular}{|c|c|c|c|c|c|}
\hline \multirow{2}{*}{ Varietas } & \multicolumn{4}{|c|}{ Pemupukan } & \multirow{2}{*}{ Rata-rata } \\
\hline & $\mathrm{P} 0$ & P1 & $\mathrm{P} 2$ & P3 & \\
\hline V1 & 4.29 & 4.56 & 4.46 & 4.59 & 4.47 \\
\hline $\mathrm{V} 2$ & 4.28 & 4.37 & 4.34 & 4.47 & 4.37 \\
\hline V3 & 4.36 & 4.52 & 4.44 & 4.52 & 4.46 \\
\hline Rata-rata & $4.31^{\mathrm{a}}$ & $4.48^{b}$ & $4.41^{\mathrm{ab}}$ & $4.53^{b}$ & \\
\hline NP BNJ 0,05 & \multicolumn{4}{|c|}{0.15} & \\
\hline
\end{tabular}

Keterangan: Angka yang diikuti oleh huruf yang sama pada baris (a,b,c), berarti perlakuan berpengaruh tidak nyata pada taraf uji BNJ $\alpha 0.05$. 
Muh. Hatta : Pertumbuhan dan Produksi beberapa Varietas Tanaman Jagung (Zea mays L. dengan Pemberian berbagai Dosis Pupuk Organik Cair dan Pupuk Kandang

\section{Bobot Pipilan Kering Pertongkol}

Hasil analisis ragam bobot pipilan kering pertongkol, menunjukan bahwa perlakuan kombinasi antara pupuk organik cair dengan pupuk kandang berpengaruh nyata, tetapi perlakuan varietas serta interaksi keduanya berpengaruh tidak nyata.

Tabel 7. Rataan Bobot Pipilan Kering Pertongkol (g) Pada Pemberian Berbagai Dosis Pupuk Organik Cair Serta Pupuk Kandang

\begin{tabular}{|c|c|c|c|c|c|}
\hline \multirow{2}{*}{ Varietas } & \multicolumn{4}{|c|}{ Pemupukan } & \multirow{2}{*}{ Rata-rata } \\
\hline & $\mathrm{P} 0$ & P1 & $\mathrm{P} 2$ & P3 & \\
\hline V1 & 148.54 & 161.93 & 158.28 & 161.57 & 157.58 \\
\hline $\mathrm{V} 2$ & 144.64 & 158.37 & 155.55 & 159.10 & 154.42 \\
\hline V3 & 147.87 & 168.75 & 151.99 & 175.51 & 161.03 \\
\hline Rata-rata & $147.02^{\mathrm{a}}$ & $163.02^{c}$ & $155.28^{b}$ & $165.39^{c}$ & \\
\hline NP BNJ 0.05 & \multicolumn{4}{|c|}{7.48} & \\
\hline
\end{tabular}

Keterangan: Angka yang diikuti oleh huruf yang sama pada baris (a,b,c), berarti perlakuan berpengaruh tidak nyata pada taraf uji BNJ $\alpha 0.05$.

Berdasarkan hasil uji BNJ $\alpha 0.05$ (Tabel 7) menunjukan bahwa perlakuan P3 berbeda nyata dengan perlakuan $\mathrm{P} 2$ dan $\mathrm{P} 0$, demikian pula dengan perlakuan P1 berbeda nyata dengan per lakuan P0, namun antara perlakuan P3 dan P1 tidak berbeda nyata, demikian pula dengan perlakuan P1 dan P2 juga tidak berbeda nyata, begitu juga dengan perlakuan $\mathrm{P} 2$ dan P0 juga tidak berbeda nyata.

\section{Bobot Kering Tongkol Perpetak}

Hasil analisis ragam bobot kering tongkol perpetak, menunjukan bahwa perlakuan kombinasi pemupukan antara pupuk organik cair dengan pupuk kandang berpengaruh nyata, tetapi varietas dan interaksi keduanya berpengaruh tidak nyata terhadap bobot kering tongkol perpetak.

Berdasarkan hasil uji BNJ $\alpha 0.05$ (Tabel 8) menunjukan bahwa perlakuan P3 berbeda nyata dengan perlakuan $\mathrm{P} 0$, namun antara perlakuan P3, P2 dan P1 tidak berbeda nyata.

Tabel 8. Rataan Bobot Kering Tongkol Perpetak Pada Pemberian Berbagai Dosis Pupuk Organik Cair Serta Pupuk Kandang

\begin{tabular}{cccccc}
\hline \multirow{2}{*}{ Varietas } & \multicolumn{4}{c}{ Pemupukan } & \multirow{2}{*}{ Rata-Rata } \\
\cline { 2 - 5 } & P0 & P1 & P2 & P3 & 4.01 \\
V1 & 3.80 & 4.11 & 4.00 & 4.12 & 4.04 \\
V2 & 3.96 & 4.05 & 4.06 & 4.11 & 4.10 \\
\hline V3 & 3.93 & 4.14 & 4.09 & 4.23 & \\
\hline Rata-Rata & $3.89^{\mathrm{a}}$ & $4.10^{\mathrm{b}}$ & $4.05^{\mathrm{b}}$ & $4.15^{\mathrm{b}}$ & \\
\hline NP BNJ 0.05 & \multicolumn{5}{c}{0.14} \\
\hline
\end{tabular}

Keterangan: Angka yang diikuti oleh huruf yang sama pada baris (a,b,c), berarti perlakuan berpengaruh tidak nyata pada taraf uji BNJ $\alpha 0.05$. 
Muh. Hatta : Pertumbuhan dan Produksi beberapa Varietas Tanaman Jagung (Zea mays L. dengan Pemberian berbagai Dosis Pupuk Organik Cair dan Pupuk Kandang

\section{Bobot Pipilan Kering 100 Biji}

Hasil analisis ragam bobot kering per 100 biji menunjukan bahwa perlakuan kombinasi pemupukan antara pupuk organik cair dengan pupuk kandang berpengaruh nyata, tetapi varietas dan interaksi keduanya berpengaruh tidak nyata terhadap bobot kering per 100 biji.

Berdasarkan hasil uji BNJ $\alpha 0.05$ (Tabel 9) menunjukan bahwa perlakuan P3 berbeda nyata dengan perlakuan P2, P1 dan P0, namun antara perlakuan P2, P1 dan P0 tidak berbeda nyata.

Tabel 9. Rataan Bobot Pipilan Kering 100 Biji (g) Pada Pemberian Berbagai Dosis Pupuk Organik Cair Serta Pupuk Kandang

\begin{tabular}{|c|c|c|c|c|c|}
\hline \multirow{2}{*}{ Varietas } & \multicolumn{4}{|c|}{ Pemupukan } & \multirow{2}{*}{ Rata-Rata } \\
\hline & $\mathrm{P} 0$ & $\mathrm{P} 1$ & P2 & P3 & \\
\hline V1 & 24.94 & 25.44 & 25.11 & 25.85 & 25.34 \\
\hline $\mathrm{V} 2$ & 24.90 & 25.88 & 24.93 & 25.86 & 25.39 \\
\hline V3 & 25.00 & 25.64 & 25.25 & 25.84 & 25.43 \\
\hline Rata-Rata & $24.95^{\mathrm{a}}$ & $25.66^{\mathrm{a}}$ & $25.10^{\mathrm{a}}$ & $25.85^{\mathrm{b}}$ & \\
\hline NP BNJ 0.05 & \multicolumn{4}{|c|}{0.32} & \\
\hline
\end{tabular}

Keterangan: Angka yang diikuti oleh huruf yang sama pada baris (a,b,c), berarti perlakuan berpengaruh tidak nyata pada taraf uji BNJ $\alpha 0.05$

\section{Bobot Kering Tongkol Perhektar}

Hasil analisis ragam pengamatan bobot tongkol per hektar menunjukan bahwa perlakuan kombinasi pemupukan antara pupuk organik cair dengan pupuk kandang berpengaruh nyata, tetapi varietas dan interaksi keduanya berpengaruh tidak nyata terhadap bobot tongkol per hektar.

Berdasarkan hasil uji BNJ $\alpha 0.05$ (Tabel 10) menunjukan bahwa perlakuan P3 berbeda nyata dengan perlakuan $\mathrm{P} 0$, namun antara perlakuan P3, P2 dan P1 tidak berbeda nyata.

Tabel 10. Rataan Bobot Kering Tongkol Perhektar (ton/ha) Pada Pemberian Berbagai Dosis Pupuk Organik Cair Serta Pupuk Kandang

\begin{tabular}{|c|c|c|c|c|c|}
\hline \multirow{2}{*}{ Varietas } & \multicolumn{4}{|c|}{ Pemupukan } & \multirow[b]{2}{*}{ Rata-Rata } \\
\hline & P0 & P1 & $\mathrm{P} 2$ & P3 & \\
\hline V1 & 7.91 & 8.55 & 8.34 & 8.57 & 8.34 \\
\hline V2 & 8.25 & 8.43 & 8.45 & 8.55 & 8.42 \\
\hline V3 & 8.18 & 8.54 & 8.53 & 8.82 & 8.52 \\
\hline RATA-RATA & $8.11^{\mathrm{a}}$ & $8.51^{\mathrm{b}}$ & $8.44^{b}$ & $8.65^{b}$ & \\
\hline NP BNJ 0.05 & \multicolumn{4}{|c|}{0.29} & \\
\hline
\end{tabular}

Keterangan: Angka yang diikuti oleh huruf yang sama pada baris $(a, b, c)$, berarti perlakuan berpengaruh tidak nyata pada taraf uji BNJ $\alpha 0.05$.

\section{Bobot Pipilan Kering Perhektar}

Hasil analisis ragam pengamatan bobot pipilan kering per hekta menunjukan bahwa perlakuan kombinasi antara pupuk organik cair dengan pupuk kandang berpengaruh nyata, tetapi 
perlakuan varietas dan interaksi keduanya berpengaruh tidak nyata terhadap bobot tongkol per hektar.

Berdasarkan hasil uji BNJ $\alpha 0.05$ (tabel 11) menunjukan bahwa perlakuan P3 namun antara perlakuan P3 dan P1 tidak berbeda nyata, demikian pula dengan perlakuan P2 dan P0 juga tidak berbeda nyata terhadap bobot pipilan kering per hektar.

berbeda nyata dengan perlakuan $\mathrm{P} 2$ dan $\mathrm{P} 0$,

Table 11. Rataan Bobot Pipilan Kering Per Hektar (ton/ha) Pada Pemberian Berbagai Dosis Pupuk Organik Cair Dan Pupuk Kandang

\begin{tabular}{|c|c|c|c|c|c|}
\hline \multirow{2}{*}{ VARIETAS } & \multicolumn{4}{|c|}{ PERLAKUAN } & \multirow{2}{*}{ RATA-RATA } \\
\hline & P0 & P1 & P2 & P3 & \\
\hline V1 & 6.19 & 6.74 & 6.59 & 6.73 & 6.56 \\
\hline V2 & 6.01 & 6.59 & 6.48 & 6.62 & 6.43 \\
\hline V3 & 6.15 & 7.03 & 6.33 & 7.31 & 6.70 \\
\hline RATA-RATA & $6.12^{\mathrm{a}}$ & $6.79^{c}$ & $6.47^{\mathrm{b}}$ & $6.89^{c}$ & \\
\hline NP BNJ & \multicolumn{4}{|c|}{0.31} & \\
\hline
\end{tabular}

Keterangan: Angka yang diikuti oleh huruf yang sama pada baris $(a, b, c)$, berarti perlakuan tidak berpengaruh nyata pada taraf uji BNJ $\alpha 0.05$.

\section{Pembahasan}

\section{Varietas}

Berdasarkan hasil analisis ragam, perlakuan varietas berpengaruh nyata terhadap parameter pengamatan tinggi tanaman 15 HST dan panjang tongkol. Hal ini menunjukkan bahwa peubah tersebut dipengaruhi oleh faktor genetik dari varietas yang diuji. Varietas Pertiwi-5 memiliki tinggi tanaman yang cenderung lebih tinggi dibandingkan dengan varietas BISI-18 dan NASA29, serta panjang tongkol yang lebih panjang.

Varietas Pertiwi-5 merupakan varietas jagung hibrida yang mudah beradaptasi pada lingkungannya. Simatupang (2007) menyatakan bahwa tingginya produksi suatu varietas disebabkan oleh varietas tersebut mampu beradaptasi dengan lingkungan. Meskipun secara genetik varietas lain mempunyai potensi produksi yang baik, tetapi karena masih dalam tahap adaptasi, sehingga produksinya lebih rendah dari pada yang seharusnya. Oleh karena itu, faktor lingkungan seperti iklim dan tanah sangat berpengaruh terhadap produksi hasil tanaman.

Parameter pengamatan tinggi tanaman pada umur 30, 45 dan 60 HST panjang daun, jumlah daun, diameter batang, diameter tongkol, bobot pipilan kering pertongkol, bobot kering tongkol perpetak, bobot pipilan kering 100 biji dan bobot kering perhektar serta bobot pipilan kering perhektar berpengaruh tidak nyata. Hal ini diduga karena kondisi fisiologis tanaman tidak jauh berbeda dari 3 varietas yang digunakan.

Varietas Pertiwi-5 merupakan varietas jagung yang memiliki potensi hasil yang tinggi yaitu mencapai 11-13 ton/ha. Selain potensi yang tinggi, diantara 3 varietas yang digunakan, panjang tongkol dan diameter tongkol juga terbaik, sehingga hasil yang 
diperoleh pun lebih tinggi dibandingkan dengan varietas BISI-18 dan NASA 29.

Bobot pipilan kering pertongkol yaitu 203.60 gram (Tabel 7), bobot kering tongkol perpetak yaitu $4.10 \mathrm{~kg}$ (Tabel 8), dan bobot pipilan perhektar yaitu 8.52 ton/ha (Tabel 10) varietas Pertiwi-5 cenderung lebih baik daripada perlakuan lainnya. Namun jumlah ini masih dibawah potensi produktivitasnya.

\section{Kombinasi Antara Pupuk Organik Cair} Dengan Pupuk Kandang

Berdasarkan hasil analisis ragam menunjukan bahwa Perlakuan kombinasi pupuk organik cair dengan pupuk kandang berpengaruh nyata terhadap semua para meter pengamatan. Hal ini diduga dikarena tingginya kandungan hara $\mathrm{N}$ dan $\mathrm{K}$ pada pupuk organik cair (Bio Pa-Ten) dan pupuk kandang, selain itu juga mengandung unsur hara makro dan mikro yang cukup lengkap sehingga meningkatkan pertumbuhan tajuk tanaman memperkuat jaringan akar dan batang tanaman. Hal ini juga diduga terjadi karena pupuk organik cair tersebut diaplikasikan melalui daun dan sela sela kutikula. Hal ini sesuai pernyataan Sutanto (2002) bahwa pupuk yang diberikan lewat daun diharapkan dapat diserap melalui mulut daun (stomata) dan sela sela kutikula, sehingga lebih cepat tersedia dan digunakan oleh tanaman untuk kebutuhan pertumbuhannya.

Tinggi tanaman, merupakan ukuran tanaman yang sering diamati baik sebagai indikator pertumbuhan maupun sebagai parameter yang digunakan untuk mengukur pengaruh lingkungan atau perlakuan yang diterapkan. Sebagai parameter pengukur pengaruh lingkungan, tinggi tanaman sensitif terhadap faktor lingkungan seperti cahaya dan air. Tanaman yang mengalami kekurangan cahaya biasanya lebih tinggi dari tanaman yang mendapat cahaya cukup (Sitompul dkk., 1995).

Kombinasi pupuk organik cair dengan pupuk kandang mempengaruhi diameter batang. Semakin rendah populasi tanaman, semakin besar diameter batang jagung. Diduga peningkatan diameter batang ini disebabkan oleh terjadinya peningkatan proses fotosintesis tanaman pada populasi rendah, sehingga fotosintat yang dialokasikan ke organ batang bertambah. Selain itu adanya persaingan cahaya menyebabkan tanaman bertambah tinggi dan diameter batang mengecil. Menurut Sitaniapessy (1985), Frizia (1993) dan Handayani (2003), diameter batang pada populasi rendah lebih besar dibandingkan dengan populasi yang lebih tinggi.

Jumlah daun dan panjang daun yang berpengaruh nyata oleh perlakuan kombinasi pupuk organik cair dengan pupuk kandang secara konsisten juga berpengaruh terhadap produksi. Hasil penelitian menunjukkan bahwa kombinasi pupuk organik cair dengan pupuk kandang berpengaruh nyata terhadap bobot pipilan kering per tongkol dan bobot pipilan kering perhektar, tetapi bobot kering tongkol perpetak, bobot kering 100 biji dan bobot tongkol per hektarnya berpengaruh tidak 
nyata. Hal ini menunjukkan bahwa kombinasi pupuk organik cair dengan pupuk kandang berpengaruh terhadap bobot kering biji jagung.

Produksi pipilan kering jagung yang diuji masih dibawah rata-rata hasil yang ada pada deskripsi varietasnya yaitu 9.1 ton pipilan kering/ha (varietas BISI-18), 11,9 ton pipilan kering/ha (varietas NASA29) dan 9,40 ton pipilan kering/ha (varietas Pertiwi-5). Diduga hal ini disebabkkan oleh tingginya curah hujan pada fase generatifnya. Tanaman jagung merupakan tanaman $\mathrm{C} 4$ yang membutuhkan intensitas radiasi surya yang tinggi untuk memaksimalkan aktivitas fotosintesisnya. Curah hujan yang tinggi menyebabkan intensitas radiasi berkurang sehingga aktivitas fotosintesis lebih rendah. Dengan demikian asimilat yang dialirkan ke organ generatif juga berkurang sehingga akan berpengaruh terhadap produksi jagung.

Hasil analisis ragam menunjukan bahwa perlakuan kombinasi antara pupuk organik cair dengan pupuk kandang berpengaruh tidak nyata pada bobot tongkol perpetak. Hal ini disebabkan oleh dosis pupuk organik cair, Pupuk kandang Ayam dan pupuk kandang sapi yang diberikan belum tepat, sehingga belum mampu memenuhi kebutuhan unsur hara yang dibutuhkan tanaman jagung (Lingga dan Marsono, 2011) menambahkan mengenai jumlah larutan yang disemprotkan tersebut sangat penting diketahui agar dosisnya jangan berlebihan. Kalau berlebihan, akibatnya akan sangat buruk. Sebaliknya kalau kekurangan, tanaman tidak akan mengalami perubahan. Menentukan dosis yang tepat untuk masing-masing tanaman sangat sulit.

Berdasarkan hasil penelitian diketahui perlakuan P3 adalah perlakuan terbaik pada bobot pipilan kering per hektar yaitu dengan pemberian kombinasi antara pupuk organik cair $5 \mathrm{ml} / \mathrm{l}$ air dengan pupuk kandang ayam 15 ton/ha dan pupuk kandang sapi 15 ton/ha yang menghasilkan rata-rata bobot pipilan kering per hektar yaitu 8.75 ton/ha.

Interaksi Antara Varietas dengan Pupuk Organik Cair, Pupuk kandang Ayam dan Pupuk Kandang Sapi

$\begin{array}{cccc}\text { Hasil } & \text { analisis } & \text { sidik } & \text { ragam } \\ \text { menunjukkan } & \text { bahwa } & \text { interaksi } & \text { antara }\end{array}$ varietas dan kombinasi pupuk organik cair dengan pupuk kandang berpengaruh tidak nyata, hal ini diduga karena unsur hara dalam pupuk organik cair dan pupuk kandang tidak memenuhi kebutuhan hara tanaman jagung, unsur nitrogen membantu proses pertumbuhan tinggi tanaman dan bobot buah, unsur $\mathrm{N}$ seharusnya dapat merangsang pertumbuhan vegetatif tanaman agar tanaman dapat mensintesis asam amino dan protein serta menyusun klorofil.

Unsur hara $P$ yang diberikan berfungsi untuk merangsang pertumbuhan akar, merangsang pembelahan sel tanaman dan memperbesar jaringan sel, serta unsur $\mathrm{K}$ yang berperan dalam proses fotosintesis sehingga tanaman jagung dapat tumbuh subur yang berpengaruh pada bobot kering tanaman. 
Muh. Hatta : Pertumbuhan dan Produksi beberapa Varietas Tanaman Jagung (Zea mays L. dengan Pemberian berbagai Dosis Pupuk Organik Cair dan Pupuk Kandang

Meskipun tidak ada perlakuan yang berpengaruh nyata, namun V3P3 (varietas Pertiwi-5 dengan Kombinasi Pupuk Organik cair dengan pupuk kandang ayam dan pupuk kandang sapi) cenderung memberikan respon terbaik pada parameter pengamatan tinggi tanaman pada umur 60 HST (Tabel 1) yaitu $217.33 \mathrm{~cm}$, Jumlah daun (Tabel 2) yiatu $12.43 \mathrm{~cm}$, diameter batang (Tabel 4) yaitu $2.51 \mathrm{~cm}$, panjang tongkol (Tabel 5) yaitu $19.83 \mathrm{~cm}$, bobot pipilan kering pertongkol (Tabel 7) yaitu 209.60 gram, bobot pipilan kering perhektar (Tabel 11) yaitu 8.97 ton/ha. Hal ini disebabkan karena V3 (Pertiwi-5 ) secara genetik memang memiliki potensi hasil sekitar 11-13 ton/ha sehingga produksi per ha akan tinggi pula.

Meskipun varietas Pertiwi-5 menunjukkan hasil terbaik dibandingkan dengan varietas BISI-18 dan NASA29, namun hal itu masih jauh dari potensi produksi yang bisa mencapai 11-13 ton per ha. Salah satu kendala yang dialami yaitu kekurangan nutrisi bagi tanaman, kondisi lingkungan kurang sesuai, dan curah hujan yang tinggi. Pertumbuhan dan produksi tanaman dapat berjalan baik apabila pemeliharaan dan pemupukan dapat berjalan baik. Pemberian unsur hara pada tanaman sangat berpengaruh terhadap proses fotosintesis yang akan berpengaruh terhadap pertumbuhan dan produksi tanaman jagung hibrida.

Berdasrkan hasil penelitian menunjukan bahwa interaksi terdapat pada faktor varietas Pertiwi-5 dengan taraf pemupukan kombinasi antara pupuk organik cair dengan pupuk kandang ayam dan pupuk kandang sapi $5 \mathrm{cc} / \mathrm{l}$ air dan 30 ton/ha (5 cc/l air dan $14.4 \mathrm{~kg} /$ petak). Hal ini dapat dilihat pada variabel bobot pipilan kering per hektar. Bobot pipilan kering per hektar terberat diperoleh dari kombinasi perlakuan V3P3 yaitu varietas Pertiwi-5 (V3) dan pemberian kombinasi antara pupuk organik cair dengan pupuk kandang ayam dan pupuk kandang sapi (P3) yang menghasilkan bobot pipilan kering yaitu 8.97 ton/ha dan bila dibandingkan dengan deskripsi jagung mendekati rata-rata hasil yaitu 9.40 ton/ha dan masih di bawah potensi hasil 9-13 ton/ha.

\section{KESIMPULAN DAN SARAN}

Kesimpulan

Berdasarkan hasil penelitian yang dilaksanakan maka dapat diambil beberapa kesimpulan sebagai berikut :

1. Varietas Pertiwi-5 cenderung memberikan respon pertumbuhan dan produksi yang terbaik dibandingkan dengan varietas BISI-18 dan varietas NASA29.

2. Kombinasi pupuk organik cair $5 \mathrm{cc} / \mathrm{l}$ air dengan pupuk kandang ayam 15 ton/ha dan pupuk kandang sapi 15 ton/ha memberikan pertumbuhan dan produksi tertinggi, dengan rata-rata bobot pipilan kering 8.75 ton/ha.

3. Interaksi antara varietas Pertiwi-5 dengan kombinasi antara pupuk organik cair dengan pupuk kandang ayam dan pupuk kandang sapi 
Muh. Hatta : Pertumbuhan dan Produksi beberapa Varietas Tanaman Jagung (Zea mays L. dengan Pemberian berbagai Dosis Pupuk Organik Cair dan Pupuk Kandang

cenderung memberikan hasil bobot pipilan kering terbanyak yaitu 8.97 ton/ha.

\section{Saran}

Berdasarkan hasil penelitian ini maka di sarankan :

1. Disarankan mengunakan varietas Pertiwi-5 dan meningkankan hasil yang lebih baik dibandingkan varietas BISI18 dan NASA29, walapun secara statistik ketiga varietas tersebut tidak berbeda.

2. Untuk menekan penggunaan pupuk kimia sintetis, maka disarankan menggunakan kombinasi pupuk organik cair (Bio-Pa-Ten) dan pupuk kandang ayam dan pupuk kandang sapi yang mampu meningkatkan pertumbuhan dan produksi tanaman jagung.

\section{DAFTAR PUSTAKA}

Agitarani, A. W. 2011. Pengaruh Pemberian Pupuk Organik Cair (POC) Terhadap Pertumbuhan Dan Produksi Tanaman Jagung Manis (Zea mayss saccharata Sturt). Fakultas Pertanian Universitas Tridinanti Palembang

Anonim,2000. Jagung(Zea mays L.) Budidaya Pertanian. 17 p.

Cahyono, 1998. Jagung dan Analisis Usaha Tani. Penerbit Kanisius, Yogyakarta. $10 \mathrm{hlm}$.

Frizia, F. 1993. Pengaruh Waktu Pemangkasan Daun dan Populasi terhadap Pertumbuhan dan Produksi Tanaman Jagung (Zea mays L.) Hibrida C-1. Tesis. Program
Pascasarjana, Institut Pertanian Bogor. Bogor. Tidak dipublikasikan.

Handayani, K.D. 2003. Pertumbuhan dan produksi beberapa varietas jagung (Zea mays L.) pada populasi yang berbeda dalam sistem tumpang sari dengan ubi kayu (Manihot esculenta Crantz.). Skripsi. Departemen Budidaya Pertanian, Fakultas Pertanian, Institut Pertanian Bogor. Bogor.

Hardjodinomo, S. 1970. Ilmu Memupuk Bina Cipta. Bandung. $30 \mathrm{hlm}$

Marsono. 2001. Petunjuk penggunaan pupuk. Penebar Swadaya Jakarta.160 hlm.

Marsono dan Sigit. 2001. Petunjuk penggunaan pupuk. Penebar Swadaya Jakarta.160 hlm.

Nugraha, U.S., Subandi dan A. Hasanuddin, 2002. Perkembangan teknologi budidaya dan industri benih jagung. Dalam: Kasriyono et al. (Eds) Ekonomi Jagung Indonesia. Badan Penelitian dan Pengembangan

Lingga P, Marsono. 2011. Petunjuk PenggunaanPupuk. Jakarta (ID): Penebar Swadaya.

Sahoo S.C. and Mahapatra, P.K. 2007. Yield and economics of sweet corn (Zea mays) as affected by plant population and fertility levels. Indian Journal of Agronomy, Volume : 52, Issue 3:

Soegito dan Adie. 1993. Teknik BercocokTanam Jagung. Penerbit Kanisius.Yogyakarta.

Subandi, I. Manwan, and Blumenschein,A. 1988. Jagung. Pusat Penelitian dan Pengembangan Tanaman Pangan, Bogor 
Muh. Hatta : Pertumbuhan dan Produksi beberapa Varietas Tanaman Jagung (Zea mays L. dengan Pemberian berbagai Dosis Pupuk Organik Cair dan Pupuk Kandang

Sutanto, R. 2002. Pertanian Organik: Sitaniapessy, P.M. 1985. Pengaruh Jarak Menuju Pertanian Alternatif dan Berkelanjutan. Yogyakarta: Kanisius.

Simatupang, P. 2007. Analisis kritis terhadap paradigma dan kerangka dasar kebijakan ketahanan pangan nasional. Forum Penelitian Agro Ekonomi 25(1): 1-18.

Tanam dan Besarnya Populasi Tanaman terhadap Besarnya Absorbsi Radiasi Surya dan Produksi Tanaman Jagung (Zea mays L.). Disertasi. Jurusan Budidaya Pertanian" Fakultas Pertanian, Institut P ertanian Bogor.

Sitompul, S.M. dan B. Guritno. 1995. Analisis Pertumbuhan Tanaman. UGM-Press. Yogyakarta. 